\title{
Effect of pre- and post-partum dietary crude protein level on the performance of ewes and their lambs
}

\author{
M.H. Ahmed ${ }^{\mathrm{a}}$, A.Z.M. Salem ${ }^{\mathrm{b}, *}$, O.A. Olafadehan ${ }^{\mathrm{c}}$, A.E. Kholif ${ }^{\mathrm{d}}$, N. Rivero ${ }^{\mathrm{e}}$, \\ M.A. Mariezcurrena ${ }^{b}$, L.M. Camacho ${ }^{\text {f }}$, M.M.Y. Elghandour ${ }^{b}$, M.U. Alonso ${ }^{b}$, A.H.A. Almaz ${ }^{a}$ \\ a Animal and Fish Production Department, Faculty of Agriculture (Saba Basha), Alexandria University, Egypt

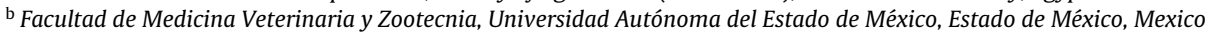

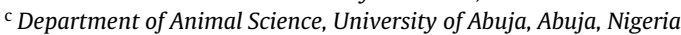 \\ d Dairy Science Department, National Research Centre, 33 Bohouth St. Dokki, Giza, Egypt \\ e Universidad Autónoma del Estado de Hidalgo, Instituto de Ciencias Agropecuarias, Área Académica de Medicina Veterinaria y Zootecnia, Mexico \\ ${ }^{\mathrm{f}}$ Unidad Académica de Medicina Veterinaria y Zootecnia, Universidad Autónoma de Guerrero, Altamirano P.O. 40660, Mexico
}

\section{A R T I C L E I N F O}

\section{Article history:}

Received 15 October 2015

Received in revised form 3 February 2016

Accepted 4 February 2016

Available online 6 February 2016

\section{Keywords:}

Birth weight

Lambing weight

Milk

Parity

Weaning weight

\begin{abstract}
A B S T R A C T
In a block randomized design, fifty-one Barki ewes weighing $38.0 \mathrm{~kg}$ in average and 2-4 years old, were used to study the effect of pre- and post-lambing dietary crude protein level (CP) of concentrates on the milk yield, milk composition and weight of ewes, and performance of their lambs. The treatments comprised supplementary concentrate containing (g/kg dry matter (DM)): (1) $110 \mathrm{CP}$ (low), (2) $130 \mathrm{CP}$ (medium) and (3) $150 \mathrm{CP}$ (high), while Egyptian berseem hay (Trifiolium alexandrinum) was the basal diet. Ewes were weighed individually biweekly, and the number of lambs dropped and nursed by ewes was recorded within $24 \mathrm{~h}$ after birth and biweekly subsequently. New-born lambs were left to suckle their dams freely, except for the period when milk yield was recorded by weighing lambs before and after suckling. Milk yield was estimated once a week. Ewes were fed the experimental diets during the last two months of pregnancy and throughout the lactation period. Ewes fed $110 \mathrm{~g} \mathrm{CP} / \mathrm{kg} \mathrm{DM}$ attained peak of milk yield earlier than those fed 130 and $150 \mathrm{~g} \mathrm{CP} / \mathrm{kg}$ DM. Total milk yield, milk fat and milk total solids, and weaning weight, average daily gain and relative growth rate of lambs were higher $(P<0.05)$ for ewes fed medium and high protein levels compared to those fed low protein level. Suckled milk was affected by protein level $(P<0.05)$; the rank order was: $110 \mathrm{CP}<130 \mathrm{CP}<150 \mathrm{CP}$. Milk protein and extractable milk were higher $(P<0.05)$ for high protein level compared to low protein level but solids-not-fat $(\mathrm{SNF})$ and lamb birth weight were not affected $(P>0.05)$ by protein level. Lamb sex, and parity and weight at lambing of ewes had no effect $(P>0.05)$ on suckled milk, extractable milk and milk yield. Whereas lamb sex and parity of ewe had no effect $(P>0.05)$ on milk composition, ewe lambing weight affected $(P<0.05)$ milk fat and SNF but not milk protein and total solids $(P>0.05)$. Weights of ewes during gestation, after lambing (post-partum weight loss) and during lactation were not affected $(P>0.05)$ by protein level, except at the 3rd month of lactation. Lamb sex, parity and lambing weight had pronounced $(P<0.05)$ effects on lamb birth weight and weaning weight. It is concluded that $150 \mathrm{~g} \mathrm{CP} / \mathrm{kg}$ DM level pre- and post-partum could be used for improved performance of ewes and their lambs while parity and weight of ewe at lambing should also be given consideration.
\end{abstract}

(c) 2016 Elsevier B.V. All rights reserved.

\section{Introduction}

The nutritional plane of an animal during gestation and in the ensuing lactation has a pronounced effect on its performance and

\footnotetext{
* Corresponding author. Fax: +20 5217221806194.

E-mail addresses: asalem70@yahoo.com, asalem70@hotmail.com (A.Z.M. Salem).
}

that of its offspring. Nutrition in the final stages of pregnancy for sheep is one of the very important factors, and depends upon many qualities after birth. During the last two months of pregnancy (the late gestation), eighty percent of the foetal growth occurs, leading to a significant increase in nutrient requirements of the ewe (Bell, 1995). Protein requirements are also increased for foetal growth and for the development of the mammary gland for colostrum production (NRC, 1985). Level of feeding in the last two month of pregnancy and after lambing affects the milk production of the 
ewe during lactation period and also growth performance of lambs (Owen, 1981). The nutrition of ewes in the pre-partum period not only affects the growth of the developing foetus, but also the ability of the ewe to supply the lamb with adequate amount of colostrum and milk post-partum (Treacher, 1983). Ocak et al. (2005) investigated the effect of feeding high dietary protein levels during late gestation of ewes on colostrum yield and lamb survival rate, and concluded that an excess of crude protein (CP) in the diet caused a decrease in colostrum yield and lamb survival. This was due to an increased lamb birth weight resulting in a higher number of lamb dystocia. Consequently, the protein level of diets fed to the pregnant ewes during this critical period of gestation and ensuing lactation has been of concern to livestock scientists. Hatfield et al. (1995) reported that birth weights of lambs were higher when the ewes were fed higher levels of protein compared to when they were fed low levels (149 vs. $113 \mathrm{~g} \mathrm{CP} / \mathrm{kg}$ dry matter (DM)) during late gestation and early lactation. It therefore becomes important to determine the pre- and post-partum dietary protein level that can maximize the production potential of ewes and the performance of their lambs. We hypothesized that increasing dietary CP of ewes during gestation and lactation could improve their body weight, lactation performance, and birth weight and growth of their lambs. The study aimed to investigate the effects of pre- and post-partum dietary protein level from concentrates on milk yield, milk composition and body weight changes of the experimental Barki ewes and the performance of their lambs.

\section{Materials and methods}

Ewes and lambs were cared and handled in accordance with the Guide for the Care and Use of Agricultural Animals in Agricultural Research and Teaching (FASS, 2010). The experimental area conditions was a temperate-tropic humid climate with winter rains and an annual average rainfall of $22 \mathrm{~mm}$ and means annual temperature between 14 and $32^{\circ} \mathrm{C}$.

\subsection{Animals, diets and experimental design}

Fifty-one 2-4 years old gestating Barki ewes were divided into three groups according to age and body weight (BW), and were randomly assigned to one of three isocaloric supplementary diets containing different $\mathrm{CP}$ levels ( $\mathrm{g} / \mathrm{kg} \mathrm{DM}$ ), $110 \mathrm{CP}$ (low), $130 \mathrm{CP}$ (medium) and $150 \mathrm{CP}$ (high), during the last two months of pregnancy and throughout four months of lactation. Earlier before the experiment, ewes were divided into three groups of similar average initial body weight $(38.0 \mathrm{~kg}$ average $\mathrm{BW})$ and were mated to Barki rams (1 ram to 17 ewes sex ratio). The rams were allowed to run with the ewes for two months during the breeding season (October-November). Composition of the supplementary concentrate and the experimental diets is shown in Table 1. Diets were served at the ewe's $2 \%$ BW twice daily at 08:00 and 16:00 h. The roughage portion of the diet (Egyptian berseem hay; Trifolium alexandrinum) was offered first followed by concentrates. Berseem hay contained (g/kg DM): organic matter 902.0, CP 167.0, CF 200.0, ether extract 20.1, and nitrogen free extract 532.9. Water and mineral blocks (contain per kg: vitamin A 55,000 IU, vitamin D3 27,500 $\mathrm{IU}$, vitamin E $300 \mathrm{IU}$, Ca 30,000 mg, Mg 5,000 mg, Mn 2,500 mg, Fe $1,800 \mathrm{mg}$, Zn $1,500 \mathrm{mg}$, Co $50 \mathrm{mg}$, I $35 \mathrm{mg}$, Se $10 \mathrm{mg}$ ) were provided free choice. The amount of supplementary concentrate fed was adjusted monthly according to ewes BW changes. Ewes were weighed individually biweekly with digital multi-purpose platform scale during the period of steaming and throughout lactation period. Number of lambs dropped and nursed by ewes was recorded, and lambs were weighed within $24 \mathrm{~h}$ after birth and biweekly thereafter until weaning. Each group of ewes and their
Table 1

Composition of the supplementary concentrate.

\begin{tabular}{|c|c|c|c|}
\hline & \multicolumn{3}{|c|}{ Dietary protein level (g/kg DM) } \\
\hline & 110 (Low) & 130 (Medium) & 150 (High) \\
\hline \multicolumn{4}{|l|}{ Ingredients (g/kg DM) } \\
\hline Soybean meal & 10.0 & 50.0 & 105.0 \\
\hline Maize & $x 820.0$ & 570.0 & 600.0 \\
\hline Barley & 140.0 & 350.0 & 265.0 \\
\hline Limestone & 20.0 & 20.0 & 20.0 \\
\hline Mineral mixture ${ }^{a}$ & 10.0 & 10.0 & 10.0 \\
\hline \multicolumn{4}{|l|}{ Chemical composition (g/kg DM) } \\
\hline Dry matter (g/kg wet material) & 875.0 & 874.1 & 860.3 \\
\hline Organic matter & 962.9 & 948.9 & 947.0 \\
\hline Crude protein & 110.3 & 131.1 & 151.1 \\
\hline Ether extract & 29.0 & 20.9 & 26.7 \\
\hline Crude fibre & 30.0 & 39.0 & 35.7 \\
\hline Nitrogen free extract ${ }^{\mathrm{b}}$ & 793.5 & 754.9 & 734.4 \\
\hline Digestible energy (Mcal/kg) ${ }^{c}$ & 3.66 & 3.60 & 3.62 \\
\hline \multicolumn{4}{|c|}{$\begin{array}{l}3 \mathrm{~g}, \mathrm{CuSO}_{4} 1 \mathrm{~g}, \mathrm{CaI} 100 \mathrm{mg} \text {, and } \mathrm{CoSO}_{4} 20 \mathrm{mg} \text {. } \\
\mathrm{b} \text { Nitrogen free extract calculated by difference }[1000 \mathrm{~g} / \mathrm{kg}-(1000 \mathrm{~g} / \mathrm{kg} \text { crude }\end{array}$} \\
\hline \multicolumn{4}{|c|}{$\begin{array}{l}\text { fibre }+1000 \mathrm{~g} / \mathrm{kg} \text { crude protein }+1000 \mathrm{~g} / \mathrm{kg} \text { ether extract }+1000 \mathrm{~g} / \mathrm{kg} \text { ash })] \text {. } \\
\text { c Calculated according to NRC }(2001) \text {. }\end{array}$} \\
\hline
\end{tabular}

lambs were housed in a partly enclosed yard. New-born lambs were left to suckle their dams freely for the first three days and were kept with their dams till weaning at 16 weeks of age, except for the period when milk yield was recorded. Throughout the experimental period, six ewes were excluded due to pathogenic infection and death; 2 ewes from the low level of protein, 1 ewe from the medium level of protein, and 3 ewes from the high level of protein.

\subsection{Determination of milk yield}

Lambs were separated from their dams at 19:00 h a day prior to the week of milk yield estimation and were weighed at 07:00 h the following morning before suckling for $15 \mathrm{~min}$. Lambs were weighed again after suckling and separated from their dams. The same procedures were repeated in the afternoon after which both lambs and their dams were housed overnight. Surplus milk (hand-milked or extractable milk) was hand milked both in the morning and afternoon. Milk consumed by lambs was taken as the difference between the lamb weight before suckling and after suckling, while daily milk yield was estimated by summing the lamb milk consumption and surplus milk in the morning and afternoon for the day. Milk yield was estimated once a week until weaning at 16th week of age.

\subsection{Chemical analysis and calculation}

Diets were analysed for their DM (\#930.15), ash (\#942.05), nitrogen (\#954.01), ether extract (\#920.39), and crude fibre (\#950.02) according to AOAC (1997) official methods. Milk samples were analysed for total solids, fat, and protein using infrared spectrophotometry (Foss 120Milko-Scan, Foss Electric, Hillerød, Denmark). Nitrogen free extract and organic matter of feeds were calculated. Relative growth rate was calculated using the equation of Brody (1945):

Relative growth rate $=\frac{W_{2}-W_{1}}{\frac{1}{2}\left(W_{2}+W_{1}\right)} \times 100$

where $W_{1}=$ weight at the beginning; $W_{2}=$ weight at the end of the period which growth rate was calculated.

\subsection{Statistical analysis}

In a block randomized design, data were analysed using the General Linear Model (GLM) of SAS (2000). Data of dead sheep were 
Table 2

Milk yield ( $\mathrm{g} / \mathrm{d}$ ) of ewes fed varying protein level during different weeks of lactation (least square means $\pm \mathrm{SE}$ ).

\begin{tabular}{lllll}
\hline \multirow{2}{*}{ Week of lactation } & \multicolumn{2}{l}{ Dietary protein level $(\mathrm{g} / \mathrm{kg} \mathrm{DM})$} & \multirow{2}{*}{ P-value } \\
\cline { 2 - 4 } & $110($ Low $)$ & 130 (Medium) & $150($ High $)$ & \\
\hline 2 & $819 \pm 47.3^{\mathrm{b}}$ & $916 \pm 60.0^{\mathrm{ab}}$ & $1098 \pm 86.5^{\mathrm{a}}$ & 0.042 \\
4 & $932 \pm 54 .^{\mathrm{b}}$ & $1008 \pm 57.6^{\mathrm{b}}$ & $1140 \pm 77.4^{\mathrm{a}}$ & 0.026 \\
6 & $886 \pm 68.9^{\mathrm{b}}$ & $1058 \pm 54.2^{\mathrm{ab}}$ & $1173 \pm 66.2^{\mathrm{a}}$ & 0.048 \\
8 & $755 \pm 70.6^{\mathrm{b}}$ & $942 \pm 61.1^{\mathrm{a}}$ & $1107 \pm 54.5^{\mathrm{a}}$ & 0.035 \\
10 & $481 \pm 37.2^{\mathrm{b}}$ & $765 \pm 59.0^{\mathrm{a}}$ & $903 \pm 45.4^{\mathrm{a}}$ & 0.041 \\
12 & $318 \pm 25.4^{\mathrm{b}}$ & $572 \pm 54.7^{\mathrm{a}}$ & $671 \pm 47.0^{\mathrm{a}}$ & 0.033 \\
14 & $175 \pm 22.2^{\mathrm{b}}$ & $402 \pm 54.3^{\mathrm{a}}$ & $488 \pm 58.7^{\mathrm{a}}$ & 0.027 \\
16 & $93 \pm 18.4^{\mathrm{b}}$ & $258 \pm 38.4^{\mathrm{a}}$ & $307 \pm 54.2^{\mathrm{a}}$ & 0.004 \\
\hline
\end{tabular}

Means with different superscripts along the row are significantly differ $(P<0.05)$.

completely excluded and the remaining data were analysed for different parameters as missed values. The effects of both treatments, pre and post-partum $\mathrm{CP}$ level, were treated as a single synergistic effect, except for certain parameters which were taken during the pre-partum period and immediately after the pre-partum phase (i.e., just at the commencement of the post-partum phase). The model describing the ewe productivity from milk and lamb was:

$Y_{\mathrm{ijklm}}=\mu+F_{i}+S_{j}+P_{k}+W_{1}+e_{i j k l m}$; where $Y_{i j k l m}$ is each individual observation for a given variable, $\mu$ is the overall mean, $F_{\mathrm{i}}$ is the fixed effect of $i$ th protein level, $S_{j}$ is the fixed effect of $j$ th lamb sex, $P_{\mathrm{k}}$ is the fixed effect of $k$ th ewe parity, $W_{\mathrm{l}}$ is the fixed effect of 1 th ewe weight at lambing, and $E_{i j k l m}$ is the residual random term. The interactions treatment $\times$ sex $\times$ parity $\times$ lambing weight were never significant, and only the effects of diet, parity and lambing weight of ewes will be reported. Comparisons of significant means were done using Duncan's multiple range test. Significance was declared at a level of $P<0.05$.

\section{Results}

Ewes fed medium ( $130 \mathrm{gCP} / \mathrm{kgDM})$ and those fed high $(150 \mathrm{~g} \mathrm{CP} / \mathrm{kg} \mathrm{DM})$ levels of protein attained peak of milk production later (6th week of lactation) than those fed low level of protein ( $4^{\text {th }}$ week of lactation). As lactation advanced after peak of milk
Table 3

Suckled milk, surplus milk or hand-milked milk and total milk yields of ewes as affected by protein level, lamb sex, parity and ewe lambing at weight (least square means $\pm \mathrm{SE}$ ).

\begin{tabular}{|c|c|c|c|c|}
\hline & \multirow[t]{2}{*}{ No. of ewe } & \multicolumn{3}{|l|}{ Milk yield (kg) } \\
\hline & & Suckled milk & Surplus milk & Total milk \\
\hline \multicolumn{5}{|c|}{ Dietary protein level (g/kg DM) } \\
\hline 110 (Low) & 15 & $44.4 \pm 2.4^{\mathrm{c}}$ & $17.3 \pm 1.2^{\mathrm{b}}$ & $61.8 \pm 3.6^{\mathrm{b}}$ \\
\hline 130 (Medium) & 16 & $58.5 \pm 3.6^{\mathrm{b}}$ & $22.6 \pm 1.9^{\mathrm{ab}}$ & $81.1 \pm 5.3^{\mathrm{a}}$ \\
\hline 150 (High) & 14 & $69.3 \pm 3.0^{\mathrm{a}}$ & $25.0 \pm 2.2^{\mathrm{a}}$ & $94.3 \pm 4.9^{\mathrm{a}}$ \\
\hline$P$-value & & $<0.001$ & 0.014 & 0.031 \\
\hline \multicolumn{5}{|l|}{ Lamb sex } \\
\hline Male & 25 & $57.5 \pm 3.5$ & $22.4 \pm 1.7$ & $79.8 \pm 4.9$ \\
\hline Female & 18 & $57.4 \pm 3.1$ & $20.9 \pm 1.6$ & $78.2 \pm 4.6$ \\
\hline$P$-value & & NS & NS & NS \\
\hline \multicolumn{5}{|l|}{ Parity } \\
\hline 1 & 22 & $54.6 \pm 4.3$ & $20.7 \pm 1.9$ & $75.4 \pm 6.2$ \\
\hline 2 & 17 & $60.9 \pm 2.1$ & $23.1 \pm 1.4$ & $84.0 \pm 3.2$ \\
\hline 3 & 6 & $56.7 \pm 2.1$ & $21.0 \pm 2.7$ & $77.8 \pm 2.5$ \\
\hline$P$-value & & NS & NS & NS \\
\hline \multicolumn{5}{|c|}{ Ewe lambing weight (kg) } \\
\hline$<34$ & 2 & $52.8 \pm 10.9$ & $21.4 \pm 7.1$ & $79.2 \pm 17.9$ \\
\hline $35-39$ & 11 & $50.6 \pm 4.8$ & $21.9 \pm 1.8$ & $72.5 \pm 6.5$ \\
\hline $40-44$ & 21 & $60.7 \pm 3.1$ & $23.5 \pm 1.6$ & $84.1 \pm 4.5$ \\
\hline $45-49$ & 7 & $60.0 \pm 5.4$ & $21.0 \pm 2.8$ & $81.0 \pm 8.2$ \\
\hline$>50$ & 4 & $58.0 \pm 9.4$ & $20.3 \pm 6.7$ & $78.3 \pm 15.1$ \\
\hline$P$-value & & NS & NS & NS \\
\hline
\end{tabular}

NS = not significant $(P>0.05)$.

Means with different superscripts along the column are significantly differ $(P<0.05)$.

production, milk yield consistently declined indicating a negative correlation between milk yield and lactation period (Table 2 ).

The amount of milk suckled by the lambs of ewes fed different dietary protein levels varied $(P<0.05)$ significantly; the rank order was: $110 \mathrm{CP}<130 \mathrm{CP}<150 \mathrm{CP} / \mathrm{kg} \mathrm{DM}$. Sex of the lambs, parity and weight at lambing of the ewes had no $(P>0.05)$ effect on the amount of milk suckled by lambs. Surplus or extractable milk was higher $(P<0.05)$ for ewes fed high level of protein compared to those fed low level of protein; however, extractable milk was not influenced $(P>0.05)$ by lamb sex, parity and weight of ewes at lambing. Total milk yield was higher $(P<0.05)$ for ewes fed medium and high protein levels than for ewes fed low protein level (Table 3 ).

Table 4

Milk composition of ewes as affected by protein level, lamb sex, parity and ewe lambing weight (least square means $\pm \mathrm{SE}$ ).

\begin{tabular}{|c|c|c|c|c|c|}
\hline & \multirow[t]{2}{*}{ Ewe no. } & \multicolumn{4}{|c|}{ Milk constituent $(\mathrm{g} / \mathrm{kg})$} \\
\hline & & Protein & Fat & Total solid & Solids-not-fat \\
\hline \multicolumn{6}{|c|}{ Dietary protein level (g/kg DM) } \\
\hline 110 (Low) & 15 & $36.4 \pm 0.8^{\mathrm{b}}$ & $33.8 \pm 0.5^{\mathrm{b}}$ & $140.8 \pm 0.5^{\mathrm{b}}$ & $106.9 \pm 0.5$ \\
\hline 130 (Medium) & 16 & $37.8 \pm 5^{\mathrm{ab}}$ & $36.0 \pm 0.8^{\mathrm{a}}$ & $144.1 \pm 0.4^{\mathrm{a}}$ & $108.0 \pm 0.6$ \\
\hline 150 (High) & 14 & $39.5 \pm 0.8^{\mathrm{a}}$ & $37.8 \pm 0.7^{\mathrm{a}}$ & $146.1 \pm 0.9^{a}$ & $108.2 \pm 0.7$ \\
\hline$P$-value & & 0.044 & 0.006 & 0.029 & NS \\
\hline \multicolumn{6}{|l|}{ Lamb sex } \\
\hline Male & 25 & $38.0 \pm 0.8$ & $35.4 \pm 0.6$ & $144.0 \pm 0.8$ & $107.8 \pm 0.7$ \\
\hline Female & 18 & $38.1 \pm 0.3$ & $36.1 \pm 0.7$ & $143.4 \pm 0.5$ & $1078 . \pm 0.4$ \\
\hline$P$-value & & NS & NS & NS & NS \\
\hline \multicolumn{6}{|l|}{ Parity } \\
\hline 1 & 22 & $38.0 \pm 0.7$ & $35.4 \pm 0.6$ & $143.3 \pm 0.8$ & $107.8 \pm 0.4$ \\
\hline 2 & 17 & $38.2 \pm 0.4$ & $36.5 \pm 0.7$ & $144.1 \pm 0.5$ & $107.5 \pm 0.6$ \\
\hline 3 & 6 & $36.2 \pm 1.0$ & $35.6 \pm 1.8$ & $143.4 \pm 1.2$ & $107.8 \pm 1.4$ \\
\hline$P$-value & & NS & NS & NS & NS \\
\hline \multicolumn{6}{|c|}{ Lambing weight (kg) } \\
\hline$<34$ & 2 & $39.2 \pm 1.0$ & $40.7 \pm 1.0^{\mathrm{a}}$ & $146.9 \pm 0.2$ & $106.2 \pm 0.5^{\mathrm{b}}$ \\
\hline $35-39$ & 11 & $37.9 \pm 0.6$ & $33.6 \pm 0.7^{b}$ & $142.1 \pm 0.6$ & $108.4 \pm 0.5^{a}$ \\
\hline $40-44$ & 21 & $38.4 \pm 0.7$ & $35.6 \pm 0.6^{\mathrm{b}}$ & $144.1 \pm 0.7$ & $108.4 \pm 0.6^{a}$ \\
\hline $45-49$ & 7 & $35.9 \pm 1.1$ & $37.8 \pm 1.1^{\mathrm{ab}}$ & $143.5 \pm 1.4$ & $105.6 \pm 0.5^{\mathrm{b}}$ \\
\hline$>50$ & 4 & $37.6 \pm 0.6$ & $37.3 \pm 2.1^{\mathrm{ab}}$ & $144.0 \pm 2.2$ & $106.6 \pm 0.6^{b}$ \\
\hline$P$-value & & NS & 0.005 & NS & 0.011 \\
\hline
\end{tabular}

NS = not significant $(P>0.05)$.

Means with different superscripts along the column are significantly differ $(P<0.05)$. 
Table 5

Weight changes $(\mathrm{kg})$ of ewes fed varying protein level during late gestation and throughout lactation periods (least square means $\pm \mathrm{SE}$ ).

\begin{tabular}{lllll}
\hline & \multicolumn{2}{c}{ Dietary protein level (g/kg DM) } & \multirow{2}{*}{ P-value } \\
\cline { 2 - 4 } & 110 (Low) & 130 (Medium) & 150 (High) & \\
\hline Weight at mating & $38.0 \pm 1.4$ & $38.1 \pm 1.1$ & $38.0 \pm 1.6$ & NS \\
Weight at late gestation & & & & \\
4th month & $40.8 \pm 1.2$ & $41.1 \pm 1.1$ & $41.2 \pm 1.4$ & NS \\
5th month & $44.8 \pm 1.4$ & $44.6 \pm 1.4$ & $46.9 \pm 1.5$ & NS \\
Weight after lambing & $41.2 \pm 1.2$ & $41.0 \pm 1.1$ & $42.5 \pm 1.2$ & NS \\
Weight during lactation & & & & \\
1st month & $40.1 \pm 1.2$ & $40.6 \pm 0.9$ & $42.1 \pm 1.0$ & NS \\
2nd month & $39.1 \pm 1.1$ & $40.0 \pm 1.1$ & $41.9 \pm 1.0$ & NS \\
3rd month & $38.2 \pm 1.2^{\mathrm{b}}$ & $39.8 \pm 1.1^{\mathrm{b}}$ & $42.2 \pm 1.3^{\mathrm{a}}$ & 0.020 \\
4th month & $40.7 \pm 1.2$ & $41.6 \pm 1.2$ & $42.2 \pm 1.1$ & NS \\
\hline
\end{tabular}

$\mathrm{NS}=$ not significant $(P>0.05)$.

Means with different superscripts along the row are significantly differ $(P<0.05)$.

Table 6

Birth weight and weaning weight of lambs as affected by protein level, lamb sex, parity and ewe lambing weight (least square means $\pm \mathrm{SE}$ ).

\begin{tabular}{llll}
\hline & No. of ewe & Birth weight $(\mathrm{kg})$ & Weaning weight $(\mathrm{kg})$ \\
\hline Dietary protein level $(\mathrm{g} / \mathrm{kg} \mathrm{DM})$ & & \\
110 (Low) & 15 & $3.28 \pm 0.15$ & $20.7 \pm 1.2^{\mathrm{b}}$ \\
130 (Medium) & 16 & $3.36 \pm 0.25$ & $23.8 \pm 0.4^{\mathrm{a}}$ \\
150 (High) & 14 & $3.67 \pm 0.12$ & $23.9 \pm 0.4^{\mathrm{a}}$ \\
$P$-value & & $\mathrm{NS}$ & 0.025 \\
Lamb sex & & & \\
Male & 25 & $3.52 \pm 0.16^{\mathrm{a}}$ & $23.8 \pm 3.4^{\mathrm{a}}$ \\
Female & 18 & $3.36 \pm 0.13^{\mathrm{b}}$ & $21.8 \pm 0.5^{\mathrm{b}}$ \\
$P$-value & & $<0.001$ & $<0.001$ \\
Parity & & & \\
1 & 22 & $3.06 \pm 0.17^{\mathrm{b}}$ & $21.2 \pm 1.8^{\mathrm{b}}$ \\
2 & 17 & $3.23 \pm 0.20^{\mathrm{ab}}$ & $22.5 \pm 0.9^{\mathrm{b}}$ \\
3 & 6 & $4.03 \pm 0.22^{\mathrm{a}}$ & $24.7 \pm 0.7^{\mathrm{a}}$ \\
$P$-value & & 0.002 & 0.016 \\
Lambing weight $(\mathrm{kg})$ & & \\
$<34$ & 2 & $2.63 \pm 0.01^{\mathrm{b}}$ & $20.1 \pm 2.8^{\mathrm{c}}$ \\
$35-39$ & 11 & $2.91 \pm 0.29^{\mathrm{b}}$ & $22.1 \pm 0.07^{\mathrm{b}}$ \\
$40-44$ & 21 & $3.69 \pm 0.14^{\mathrm{ab}}$ & $24.0 \pm 0.8^{\mathrm{a}}$ \\
$45-49$ & 7 & $4.09 \pm 0.23^{\mathrm{a}}$ & $24.6 \pm 1.0^{\mathrm{a}}$ \\
$>50$ & 4 & $3.88 \pm 0.33^{\mathrm{a}}$ & $23.2 \pm 0.8^{\mathrm{ab}}$ \\
$P$-value & & 0.044 & 0.025 \\
\hline
\end{tabular}

NS = not significant $(P>0.05)$.

Means with different superscripts along the column are significantly differ $(P<0.05)$.

Beside level of protein and weight of ewes at lambing which had a pronounced effect on milk composition, lamb sex and parity of ewe had no effect $(P>0.05)$. Milk fat was higher $(P<0.05)$ for high protein level than for low protein level. Whereas solids-notfat (SNF) was similar $(P>0.05)$ among the protein levels, milk fat and total solids were higher $(P<0.05)$ for medium and high protein levels relative to low protein level (Table 4).

Weights of ewes at mating, late pregnancy, lambing, and throughout lactation period were not $(P>0.05)$ affected by protein level during the last two months of gestation and throughout the lactation, except at 3rd month of lactation. Lactating ewes fed high protein level at $3 r d$ month of lactation were heavier $(P<0.05)$ than ewes fed medium and low protein levels (Table 5 ).

Whereas level of protein had no $(P>0.05)$ effect on lamb birth weight and lamb sex, parity and lambing weight of ewes affected $(P<0.05)$ lamb birth weight. Male lambs were heavier $(P<0.05)$ at birth than female lambs. Ewes in their 3rd parity produced heavier lambs at birth relative to ewes in their 1 st parity. Similarly, heavier ewes in the weight range of $45-49 \mathrm{~kg}$ and those above $50 \mathrm{~kg} \mathrm{BW}$ at lambing produced lambs with heavier birth weight compared to ewes with lower weight at lambing (Table 6). Lambs of primiparous ewes were lighter $(P<0.05)$ at birth than those of ewes with more than 3 parturitions. Weaning weight (WW) of lambs was sig-
Table 7

Weight changes of lambs from birth to weaning of ewes fed varying protein level pre- and post-partum (least square means $\pm S E$ )

\begin{tabular}{lllll}
\hline \multirow{2}{*}{ Item } & \multicolumn{2}{l}{ Dietary protein level (g/kg DM) } & \multirow{2}{*}{ P-value } \\
\cline { 2 - 4 } & 110 (Low) & 130 (Medium) & 150 (High) & \\
\hline Total weight gain $(\mathrm{kg})$ & $17.4 \pm 0.6^{\mathrm{b}}$ & $20.4 \pm 0.3^{\mathrm{a}}$ & $20.2 \pm 0.4^{\mathrm{a}}$ & 0.039 \\
Average daily gain $(\mathrm{g})$ & $177.2 \pm 21.1^{\mathrm{b}}$ & $208.1 \pm 11.5^{\mathrm{a}}$ & $206.3 \pm 11.2^{\mathrm{a}}$ & 0.002 \\
Relative growth rate (\%) & $144.4 \pm 2.0^{\mathrm{b}}$ & $150.5 \pm 1.5^{\mathrm{a}}$ & $147.3 \pm 2.0^{\mathrm{a}}$ & 0.012 \\
\hline
\end{tabular}

Means with different superscripts along the row are significantly differ $(P<0.05)$.

nificantly $(P<0.05)$ affected by pre- and post-partum protein level, lamb sex, dam parity and ewe weight at lambing (Table 6).

Total weight gain, average daily gain and relative growth rate were superior $(P<0.05)$ for lambs born to ewes fed medium and high protein levels pre- and post-partum relative to the lambs of ewes fed low protein level pre- and post-partum (Table 7).

\section{Discussion}

The peak of milk production (4th to 6th week of lactation) is in consonance with earlier reports on Awassi ewes (Al-Jassim et al., 1999). Milk yield consistently declined with advancing lactation indicating a negative correlation between milk yield and lactation period. Similar observations were reported by Olafadehan and Adewumi (2010) for pre-partum supplemented Bunaji cows.

Increasing dietary protein level increased the amount of milk suckled by the lambs and also surplus or extractable milk production. The amount of milk available for suckling is a function of the milk production of the dam; hence, ewes fed $150 \mathrm{~g} \mathrm{CP} / \mathrm{kg} \mathrm{DM}$ supplied more milk because they equally had the higher milk production. Increased milk yield for ewes fed medium and high protein levels may be due to the fact that high level of protein causes an increase in the amount of protein leaving the rumen and thus alters the amounts and proportions of amino acids available for absorption in the plasma which improve udder development and milk production (Abdalla et al., 2012; Kholif et al., 2014, 2015). Moreover, Arnold et al. (1977) observed that increasing dietary protein level form 80 to $140 \mathrm{~g} / \mathrm{kg}$ DM gave a 15\% increase in milk yield. In the current study, milk yield was improved by 31.3 and $52.6 \%$ for medium and high protein levels respectively compared to low protein level. Suckled milk accounted for about 73.5, 72.2 and 72.0\% of the total milk yield of ewes fed high, medium and low protein levels respectively.

In concurrence with earlier studies (Abdalla et al., 2012), milk composition in the current study was affected by nutritional plane. However, the marked effect of protein level on milk fat and protein in the present study contradicts previous reports (Olafadehan and Adewumi, 2010; Abdalla et al., 2012), but agrees with the submissions of Al-Saigh and Khauzai, 1991.

Lack of treatment effect on weight of ewes at late pregnancy, lambing and end of lactation period suggests that all the ewes were in good condition, and the diets met their requirements for gestation and lactation. This implies that the diets supported foetal development and lactation without the ewes metabolising their body reserves. Dawson et al. (1999) also did not find any effect of protein level on post-partum live weight of experimental ewes. However, Kidane et al. (2010) observed that ewes fed on a higher protein diet were heavier than ewes on a lower protein diet. Cases of diet effect on pre- and post-partum BW have been attributed to the mobilization of the body reserves by dams to either support foetal development or meet up with requirements for lactation (Olafadehan and Adewumi, 2009). Abdalla et al. (2012) also reported that feeding level had no effect on pre- and post-lambing weight of Barki ewes. However, Aziz and Al-Dabbagh (2008) noted that ewes on high plane of nutrition had more BW gain than those 
on low level feeding during the last period of pregnancy, but diet had no effect on BW at lambing and weaning.

At birth, male lambs were heavier than female lambs. Moreover, heavier lambs were produced from ewes in their 3rd parity than ewes in their 1st parity. There are conflicting reports on effect of pre-partum feeding level of ewes on birth weight of their lambs. While Annett et al. (2008) and Abdalla et al. (2012) noted that prepartum feeding level of ewes produced no effect on birth weight of their lambs, Ocak et al. (2005) and Hashemi et al. (2008) reported the contrary. The lack of protein level effect on birth weight of lambs produced by the experimental ewes confirmed the earlier conjecture that the diets met the requirements of the ewes for pregnancy and foetal growth because mobilization of body reserves to support foetal growth, a situation experienced under under-nutrition condition, would have resulted in reduced ewes weight at lambing which was not similarly affected by the protein level in the present study. Higher birth weight of male lambs than female lambs is supported by previous reports (Mousa et al., 2013; Rojo-Rubio et al., 2016). The significantly higher birth weight of lambs by older dams (3rd parity) than the lambs by younger ewes (1st parity) may be attributed to the fact that many of the young ewes might not have reached adult size when they were bred and thus continued to grow during gestation resulting in a competition with the foetus for available nutrients. This is in agreement with the findings of Abbasi et al. (2012) and Mousa et al. (2013). Higher birth weight of lambs of heavier ewes agrees with previous findings (Mokhtar et al., 1991; Celi et al., 1994). Similarly, Ibrahim et al. (2015) showed that heavier cows produced heavier calves at birth. Higher WW of lambs fed medium and high protein levels is due to higher milk yield of their dams and thus milk suckled by them. Abd-Allah (2013) reported higher WW for lambs whose dams were fed high protein diet pre- and post-partum compared to those whose dams were placed on maintenance diet. Also, Annett et al. (2008) found a significant effect of protein level of the diets of gestating ewes on the weaning weight of their lambs. However, Abdalla et al. (2012) observed no effect of feeding diets containing different dietary protein level to dams on the WW of their lambs. Higher WW of male lambs is probably due to their higher birth weight, in agreement with earlier reports (Mousa et al., 2013). Heavier WW weight of lambs of multiparous ewes in their 3rd parity compared to lambs of primiparous ewes agrees with the reports of Abbasi et al. (2012) and Mousa et al. (2013), but disagrees with other findings (AbdAllah, 2013), who reported no effect of parity on WW. Higher WW of lambs of heavier dams concurs with previous findings (Alkass et al., 1985).

The superior total weight gain, average daily gain and relative growth rate of lambs of dams fed high and medium protein level pre- and post-partum were due to higher birth weight and milk consumption of these lambs. Parallel results were obtained by AbdAllah (2013). However, Ocak et al. (2005) found no effect of feeding diets with varying protein level to gestating ewes on the growth rate of their lambs. Variation in results may be due to differences in diet, parity and season of the experiment, management, etc.

\section{Conclusions}

High and medium pre- and post-partum protein improved suckled milk by lambs, and milk fat, total solids and production relative to low protein level. Similarly, total weight gain, average daily gain and relative growth rate were higher for lambs born to ewes fed medium and high protein levels pre- and post-partum than those of ewes fed low protein level. However, parity and weight of ewe at lambing should also be given consideration for enhanced performance. Under the experimental condition, $150 \mathrm{~g}$ dietary $\mathrm{CP} / \mathrm{kg}$ DM pre- and post-partum could be used to improve performance of ewes and their lambs. Further studies should, however, be carried out to investigate the different effects promoted by the diet during pre- and post-partum periods on feed utilization, and milk production and composition.

\section{Conflict of interests}

The authors declare no conflict of interest.

\section{References}

Abbasi, M.A., Abdollahi-Arpanahi, R., Maghsoudi, A., Vaez Torshizi, R., Nejati-Javaremi, A., 2012. Evaluation of models for estimation of genetic parameters and maternal effects for early growth traits of Iranian Baluchi sheep. Small Ruminant Res. 104 (1-3), 62-69.

Abdalla, E.B., Abou Ammou, F.F., El-Shafie, M.H., El-Bordeny, N.E., Hamida, R.M. 2012. Effect of feeding levels on the productive performance of Barki sheep. Egypt J. Sheep Goat Sci. 7, 11-15.

Abd-Allah, M., 2013. Effects of parity and nutrition plane during late pregnancy on metabolic responses, colostrum production and lamb output of Rahmani ewes. Egypt J. Anim. Prod. 50, 132-142.

Al-Jassim, R.A.M., Aziz, D.I., Zorah, K., Black, J.L., 1999. Effect of concentrate feeding on milk yield and body-weight change of Awassi ewes and the growth of their Lambs. J. Anim. Sci. 69, 441-446.

Alkass, J.E., Juma, K.H., Aldoori, T.S., 1985. Studies on some economic characteristics in Awassi and Arabi sheep: 1 Birth and weaning weight. World Rev. Anim. Prod. 21, 57-59.

Al-Saigh, M.N.R., Khauzai, A.A.D., 1991. Effect of age and level of feeding on 2- milk production of Arabi ewes. World Rev. Anim. Prod. 26, 37-42.

Annett, R.W., Carson, A.F., Dawson, L.E.R., 2008. Effects of digestible undegradable protein (DUP) supply and fish oil supplementation of ewes during late pregnancy on colostrum production and lamb output. Anim. Feed Sci. Technol. $146,270-288$

AOAC, 1997. Association of Official Analytical Chemists Official Methods of Analysis, 16th ed. AOAC, Arlington, VA, USA.

Arnold, G.W., Wallace, S.R., Boer, E.S., 1977. Effect of lupin grain supplementation on birth-weight and growth rate and on milk production of Merino ewes. Aust. J. Exp. Agric. Anim. Husb. 17, 915-919.

Aziz, K.O., Al-Dabbagh, A.S.S., 2008. Effect of plane of nutrition during late pregnancy and early lactation on milk production and lambs growth of Hamadni ewes. Jordan J. Agric. Sci. 4, 148-157.

Bell, A.W., 1995. Regulation of organic nutrient metabolism during transition from late pregnancy to early lactation. J. Anim. Sci. 73, 2804-2819.

Brody, S., 1945. Bioenergetics and Growth. Reinhold Pub. Co., NY.

Celi, R., Cosention, E., Melodia, L., Trana, A., 1994. Variations in production traits and body weight of ewes in relation to breeding system and concentrate supplementation during pregnancy. Anim. Breeding Abst. 62, 2588.

Dawson, L.E.R., Carson, A.F., Kilpatrick, D.J., 1999. The effect of the digestible undegradable protein concentration of concentrates and protein source offered to ewes in late pregnancy on colostrum production and lamb performance. Anim. Feed Sci. Technol. 82, 21-36.

FASS, 2010. Guide for the care and use of agricultural animals in agricultural research and teaching. Fed. Anim. Sci. Soc., Champaign, IL.

Hashemi, M., Zamiri, M.J., Safdarian, M., 2008. Effect of nutritional level during late pregnancy on colostral production and blood immunoglobulin levels of Karakul ewes and their lambs. Small Ruminant Res. 75, 204-209.

Hatfield, P.G., Snowder, G.D., Head, J.W.A., Glimp, H.A., Stobart, R.H., Besser, T., 1995. Production by ewes rearing single or twin lambs: Effects of dietary crude protein percentage and supplemental zinc methionine. J. Anim. Sci. 73, 1227-1238.

Ibrahim, E.A., Ibrahim, A.I., Faysal, H.I., Abdurahman, M., Mohamed-Khair, A.A., 2015. Impact of genetic and non-genetic factors on birth weight of crossbred red angus and simmental with local cattle. Am. J. Agr. Sci. 2, 80-84.

Kholif, A.E., Gouda, G.A., Morsy, T.A., Salem, A.Z.M., Lopez, S., Kholif, A.M., 2015 Moringa oleifera leaf meal as a protein source in lactating goat's diets: feed intake, digestibility, ruminal fermentation, milk yield and composition, and its fatty acids profile. Small Ruminant Res. 129, 129-137.

Kholif, A.E., Khattab, H.M., El-Shewy, A.A., Salem, A.Z.M., Kholif, A.M., El-Sayed, M.M., Gado, H.M., Mariezcurrena, M.D., 2014. Nutrient digestibility, ruminal fermentation activities, serum parameters and milk production and composition of lactating goats fed diets containing rice straw treated with Pleurotus ostreatus. Asian Australas J. Anim. Sci 27, 357-364.

Kidane, A., Houdijk, J., Athanasiadou, S., Tolkamp, B., Kyriazakis, I., 2010. Nutritional sensitivity of periparturient resistance to nematode parasites in two breeds of sheep with different nutrient demands. Br. J. Nutr. 104, 1477-1486.

Mokhtar, M.M., Abdel Barry, H.T., Younis, A.A., El-Gabbas, H., 1991. Growth and mature size in fat-tailed Barki sheep. Egypt J. Anim. Prod. 28, 39-46.

Mousa, E., Monzaly, H., Shaat, I., Ashmawy, A., 2013. Factors affecting birth and weaning weights of native Farafra lambs in upper Egypt. Egypt J. Sheep Goat Sci. 8, 1-10.

NRC, 1985. Nutrient Requirements of Sheep, 6th ed. National Academy Press, Washington D.C. 
Ocak, N., Cam, M.A., Kuran, M., 2005. The effect of high dietary protein levels during late gestation on colostrum yield and lamb survival rate in singleton-bearing ewes. Small Ruminant Res. 56, 89-94.

Olafadehan, O.A., Adewumi, M.K., 2009. Productive and reproductive performance of strategically supplemented free grazing prepartum Bunaji cows in the agropastoral farming system. Trop. Anim. Health Prod. 41, 1275-1281.

Olafadehan, O.A., Adewumi, M.K., 2010. Milk yield and composition of prepartum Bunaji cows supplemented with agroindustrial by-products in smallholder dairy production systems. Trop. Subtrop. Agroecosyst. 12, 557-564.

Owen, J.B., 1981. Sheep Production. The English Book. Socand Bailliere Tindall, London.
Rojo-Rubio, R., Kholif, A.E., Salem, A.Z.M., Mendoza, G.D., Elghandour, M.M.Y Vazquez-Armijo, J.F., Lee-Rangel, H., 2016. Lactation curves and body weight changes of Alpine, Saanen and Anglo Nubian goats as well as preweaning growth of their kids. J. Appl. Anim. Res. 44, 331-337.

SAS, 2000. Statistical Analysis System. User's Guide: Statistics. SAS Institute Inc., Cary NC, USA

Treacher, T.T., 1983. Nutrient requirements for lactation in the ewe. In: Haresign, W. (Ed.), Sheep Production. Butterworths, London, p. 576. 